\title{
THE RELATIONSHIP BETWEEN HORMONAL CONTRACEPTIVE USE AND THE RISK OF BREAST CANCER AMONG WOMEN IN KEDIRI, EAST JAVA
}

\author{
Nurita Nilasari Bunga Kharisma Arifiana Putri, Eko Sri Wulaningtyas
}

Academy of Midwifery Medika Wiyata, Kediri, East Java

\begin{abstract}
Background: In 2020, there were 2.3 million women diagnosed with breast cancer and 685,000 deaths globally. An analysis of data from more than 150,000 women who participated in previous 54 epidemiologic studies showed that, overall, women who had ever used oral contraceptives had a slight (7\%) increase in the relative risk of breast cancer compared with women who had never used oral contraceptives. This study aimed to determine the relationship between hormonal contraceptive use and the risk of breast cancer among women.

Subjects and Method: This was a cross-sectional study conducted in Gambiran Hospital, Kediri, East Java, in June 2021. A total of 38 hormonal contraceptive users was selected by total sampling. The dependent variable was breast cancer. The independent variable was hormonal contraceptive use. The data were collected by questionnaire and analyzed using odds ratio and chi-square.

Results: Hormonal contraceptive use was associated with an increased risk of breast cancer, but it was statistically not significant $(\mathrm{OR}=1.37 ; 95 \% \mathrm{CI}=0.62$ to $3.32 ; \mathrm{p}=0.428)$.

Conclusion: Hormonal contraceptive is associated with breast cancer, but it is statistically not significant.
\end{abstract}

Keywords: hormonal contraceptive, risk factor, breast cancer

\section{Correspondence:}

Nurita Nilasari Bunga Kharisma Arifiana Putri. Academy of Midwifery Medika Wiyata. Jl. Dr. Sahardjo 16 Campurejo Mojoroto Kediri, East Java. Email: nuritanilasario1@gmail.com. Mobile: +6281259798269 